\title{
Plant-animal interactions affecting plant establishment and persistence on revegetated rangeland
}

\author{
STEVE ARCHER AND DAVID A. PYKE
}

\section{Abstract}

The role of ungulate grazing in shaping rangeland ecosystems is well known relative to other important plant-animal interactions such as pollination, seed dispersal, granivory, and belowground herbivory. Successful rangeland revegetation may be enhanced by strategies that favor certain groups of animals and discourage others. Many perennial forbs and shrubs require animals for successful pollination, reproduction, and subsequent maintenance of species on a site; however, pollination biology of many rangeland plants and pollinator abundances at potential revegetation sites are largely unknown. Granivory may be significant in some locations and planning and design of revegetation areas may be improved by implementing principles of seed escape mechanisms, such as predator satiation, seed escape in space (low perimeter-to-area ratio for revegetation site), and seed escape in time (synchronous or staggered timing for nearby revegetation sites). Seedling establishment may be associated with invertebrate population levels which need to be considered in future revegetation projects. Timing and site preparation are important in limiting belowground herbivory. Animals can serve as dispersal agents of seeds. Livestock dosed with desirable seeds can disperse them in their dung across the landscape, thereby creating patches of desirable plants. If revegetation sites will be grazed by livestock, then managers should choose plant species that tolerate rather than avoid grazing and should apply adequate management to establish and maintain plant populations. Seeds inoculated with mutualistic species such as mycorrhizae, nitrogen-fixing bacteria, or actinomycetes may enhance establishment, productivity, and nutrient quality of rangeland species while increasing rates of succession.

Key Words: defoliation, granivory, grazing, pollination, revegetation, seed dispersal, seed predation

An awareness of the dynamic interactions between plants and the heterotrophs which use them (e.g., microbes, granivores, frugivores, folivores, etc.) is central to understanding processes that regulate ecosystem structure, population dynamics, the flow of energy and the cycling of nutrients through time (see Crawley 1983). The role of herbivores in shaping ecosystem characteristics via grazing activities has been well-studied relative to other important plant-animal interactions such as microbial associations, pollination, seed predation, and seed dispersal. In our tendency to focus on how grazers modify plant species composition and productivity, we often overlook the reverse consideration that the mixture of plant species or of growth forms may dictate the kind and abundance of animals utilizing a site.

The success of restoration and reclamation efforts may be enhanced by formulating strategies which may favor certain

\footnotetext{
Authors are associate professor, Department of Rangeland Ecology and Management, Texas A\&M University, College Station 77843-2126; and assistant professor, Department of Range Science and the Ecology Center, Utah State University, Logan 84322-5230.

Authors wish to thank A.L. Aradottir, N. Fowler, T.E. Fulbright, D.N. Ueckert, and $S$. Zitzer for critical review of earlier drafts of the manuscript; C. Call and $B$ Roundy for organizing the symposium that brought about our collaboration. Two anonymous reviewers made helpful suggestions which improved the final draft. This paper was partially funded by NSF grant BSR 87-05492, Utah Mineral Lease Funds NR-1181, and Utah Agricultural Experiment Station Project 641 and 891 to DAP and by USDA grants 89-38300-4508 and 89-38300-3625 and Texas Agricultural Experiment Station Project 6717 to SA.

Manuscript accepted 6 May 1991
}

groups of animals and discourage others. For example, seed predation might be reduced by encouraging animals that prey upon granivores. Providing perching structures for birds of prey might also encourage frugivorous passerines to rest and defecate seeds on reclaimed sites, thereby enhancing plant immigration and species diversity (McDonnell and Stiles 1983, Vander Wall and MacMahon 1984). Strategies to encourage the dissemination of desirable or to discourage the dissemination of undesirable seeds by livestock may also warrant consideration. In a companion paper (Pyke and Archer 1991), we discussed interactions among autotrophic organisms in relation to plant establishment on revegetated rangeland. In this paper, we will address animal impacts on seedling establishment, where the term animal will take a broad definition including heterotrophic microbes such as fungi and bacteria.

\section{Plant-Microbe Associations}

The importance of plant-microbe relationships in ecosystem structure and function is widely recognized. In disturbed ecosystems, reductions in plant biomass reduce energy for soil organisms. Microbes associated with plants (rhizosphere organisms), do not, in general, appear to successfully switch from living plant substrates to detritus (Corman et al. 1987, Janos 1988, Perry et al. 1987). As a result, their abundance is linked directly to plant abundance and physiological activity. Reductions in activity of mutualistic or free-living rhizosphere microbes can subsequently influence soil fertility (e.g., by influencing nitrogen fixation) and structure (e.g., aggregate stability [Lynch and Bragg 1985]) and thus, the capacity of soils to store and deliver resources. The absence of microbes (e.g., mycorrhizae) can severely limit seedling establishment, plant growth, and plant survival. As a result, the success of revegetation efforts may be significantly influenced by the extent to which microbial activity in soils has been affected and by the extent to which linkages between plants and soil organisms are subsequently restored (Perry et al. 1989).

Vesicular-arbuscular (VA) mycorrhizae and symbiotic nitrogenfixing bacteria (Rhizobium spp.) or actinomycetes (e.g., Frankia spp.) may enhance host and nonhost plant establishment, increase productivity, enhance exploitation of soils for water and nutrients, increase nutrient quality of foliage, and increase rates of succession on reseeded sites (Parker and Chatel 1982, Miller 1987, Allen 1988). These root symbionts may be particularly important to seedlings, which have less storage tissue and smaller root systems than adult plants (St. John and Coleman 1983). Most inferences regarding the importance of root symbionts to nutrient uptake and plant production are based on examinations of surficial roots or on estimations of symbiont abundance in surficial soils. Rhizobial populations are often small or nondetectable under these circumstances; however, inferences based on these criteria may underestimate the importance of microbe-root associations. Large rhizobial populations and viable root nodules may occur deeper in the soil profile (e.g., 2 to $10 \mathrm{~m}$ for honey mesquite \{Prosopis glandulosa Torr.\}) where moisture conditions are more favorable and nutrient concentrations rarely reach inhibitory levels (Virginia et al. 1986, Jenkens et al. 1988, Johnson and Mayeux 1990).

Mycorrhizae, rhizobium, and actinomycetes are facultative symbionts that may or may not be present in rangeland soils in 
adequate numbers and of the appropriate species before reseeding. Levels of mycorrhizal infection can vary significantly between soils (Frankland and Harrison 1985). Erosion and soil disturbances can reduce the inoculation by VA mycorrhizae (Moorman and Reeves 1979, Powell 1980, Allen 1988), and Rhizobium (Trinick 1982, Lowther et al. 1987a,b) when native populations of these microbes do exist. Where microbial populations have been substantially reduced by severe disturbance, the probability and rate of spore dispersal into a site will depend on the geographic scale of the disturbance and on the proximity to less disturbed areas which serve as sources of spores (E. Allen 1989). Poor legume establishment on freshly plowed land in western Australia was attributed to soil fungi that produced antibiotics which inhibited Rhizobium growth (Holland 1966, Holland and Parker 1966). Plant establishment was enhanced by applying a fungicide or by allowing the field to remain fallow until the fungi became less prevalent.

Site conditions may dictate levels of infection, reproduction, and nutrient acquisition by these microbes. Soil $\mathrm{pH}$ influences the success of infection of several species of VA mycorrhizal fungi and Rhizobium and influences their saprophytic growth with host plants (Porter et al. 1987a,b, Rice et al. 1977). Post-establishment persistence and spread of alfalfa (Medicago sativa $\mathbf{L}$. and $M$. falcata L.) inoculated with Rhizobium may depend on seedlings emerging within interplant zones and becoming infected with effective Rhizobium. Rhizobium density may decrease with increasing distance from inoculated plants, such that soil samples 50 to 100 $\mathrm{cm}$ from inoculated plants contain no Rhizobium (Lowther et al. $1987 \mathrm{~b}$ ). While seeds inoculated with VA mycorrhizae or with nitrogen-fixing bacteria before dissemination can facilitate plantmicrobe symbiosis (Alexander 1977), this technology is available for only a few species (M. Allen 1989).

Establishment and persistence of vascular plants in restoration projects might be facilitated if concentrated efforts were made to introduce free-living nitrogen-fixing bacteria, lichens, or bluegreen algae. Cryptogamic crusts may offer particular potential since they enhance surface soil stability, improve water infiltration, and provide pulsed inputs of plant-available nitrogen (Loope and Gifford 1972, Rychert and Skujins 1974, Kleiner and Harper 1977). Establishment of cryptogamic crusts in early stages of restoration may enhance chances for successful seedling establishment and for subsequent plant growth and reproduction (St. Clair et al. 1984).

\section{Pollination}

Persistence of a species on a site depends on vegetative regeneration, on the production of new offspring from seed, or on both. Long-lived perennials in arid and semiarid systems may endure adverse conditions and persist by vegetative propagation until the occurrence of a rare window of opportunity for seedling establishment. Allocation of resources to annual flower and seed production may be rather high since the appearance of such windows is unpredictable. Although the resource status of a plant strongly influences its seed output (Stephenson 1981), pollinator service and flower:pollinator ratios may also be important determinants of levels of seed production (Simpson et al. 1977, Silander and Primack 1978, Zimmerman 1980). In some cases, plants may compete for pollinators as well as for light or soil resources (Waser 1978).

Most grasses used in revegetation of rangelands are wind pollinated and are not dependent on animals. In contrast, many perennial forbs and shrubs are insect pollinated and are facultative or obligate outcrossing plants. Cross-pollination is desirable, since the offspring of self-pollinated plants may suffer inbreeding depression. The availability of pollinators for many plants may not be a problem (Bierzychudek 1981, 1982). Pollination success in other cases may largely depend on the presence of a certain insect species (Augspurger 1980, 1981). The pollination biology of many rangeland plants is largely unknown. In addition, the functional abundance of pollinators on sites slated for restoration may be difficult to determine. In the absence of such information, inferences may be drawn from small-plot experiments where resource limitations to seed production are overcome. If seed production among plants on such plots remains low, the possibility of inadequate pollination should be considered.

\section{Seed Predation}

Seeds are subject to predation before, during, and after dispersal (Janzen 1971). The primary granivores of arid and semiarid regions of North America are rodents, whereas in South America, Australia, and Africa ants may be the primary seed predators (Mares and Rosenzweig 1978, Buckley 1982). Levels of seed predation by rodents may be particularly high in disturbed habitats, which may serve as dispersal sinks (Martell 1983). Where granivores are abundant, the composition and spatial pattern of vegetation may reflect seed consumption and the differential distribution of seed predators as well as edaphic variation and interspecific competition (e.g., Bartholomew 1970, Louda 1982, Smith et al. 1989). Rodents and ants have been shown to decrease seed reserves in annual grasslands and desert annual communities by 30 to $80 \%$ (Batzli and Pitelka 1970, Nelson and Chew 1977, Borchert and Jain 1978, Reichman 1979, Abramsky 1983). In old-field communities, forb seeds were removed at rates of 3 to $45 \%$ per day (Mittlebach and Gross 1984). Seed predation is potentially a major factor contributing to the failure of vegetation establishment when seed is broadcast (Nelson et al. 1970), but drilling of seeds may not insure their escape from predators. Excavation of buried seeds, especially large seeds like vetch (Vicia spp.), is known to occur (Reynolds 1950, 1958). Applications of rodenticides and colored dyes have been suggested to reduce seed losses due to rodents and birds during revegetation (Valentine 1989), but these may not be economically feasible.

There are several evolutionary mechanisms which enable seeds to persist in the face of predation. Janzen (1970) has proposed 2 escape mechanisms: escape in space and in time. Escape from predators in space can occur when seeds are dispersed away from parent plants or from cover which may harbor predators (Wilson and Janzen 1972, Webb and Wilson 1985). In planning revegetation areas, a site with a low perimeter-to-area ratio (e.g., large, circular area) will provide escape in space for the majority of seeds by providing a smaller edge from which predators may penetrate the revegetation area. Escape from predators in time can result when seeds are dispersed at unpredictable times or at times when predators are not abundant. Escape can also occur when plants produce more seeds than predators can consume. Known as predator satiation, this phenomenon is exemplified by mast seeding in trees, which appears to correspond to random fluctuations in weather (Silvertown 1980). Predators surviving lean periods between crops will be swamped by food in mast years.

Application of these concepts to revegetation would involve documenting seasonal population dynamics of seed predators to assure that sowing and germination of seeds would occur during periods of low predator abundance. Where adjacent sites are slated for revegetation, seed should be sown in all sites in the same year. This synchronous approach to revegetation will minimize the likelihood that seed predator populations will increase or be maintained over a series of years as might be the case where the same (or a greater) number of seeds are sown in different locations over a series of years. A synchronous approach is similar to the evolved mechanism of synchronous seed production found in bamboo (Janzen 1976). An alternative method of revegetating adjacent sites would be to stagger revegetation so that granivore populations on the treated site return to pre-reseeding levels before nearby sites are 
seeded. Providing perching or nesting structures (natural or artificial) for raptors (MacMahon 1987) or approach cover for fox, coyote, bobcat, etc., may help increase predation on granivorous rodents and mitigate their impact. Providing alternative, preferred foods for granivores can reduce the seed consumption of desirable species in the short term, therefore allowing desirable seeds to germinate before predator populations increase. For example, survival of Douglas fir seed was improved from 5 to $50 \%$ by providing sunflower seeds in clear-cut areas of forest (Sullivan 1979). Allowances for seed predation should be taken into account when estimating seeding rates that may be required to achieve desired plant densities.

\section{Seed Dispersal}

Dispersal of plant propagules (see review by van der Pijl 1972 and Willson et al. 1990) is of central importance in succession and restoration. This is especially true when dealing with large areas where it is not economically feasible to conduct extensive reseeding or when the probability of achieving successful establishment in any given year is low. In such cases, one strategy might be to concentrate resources such that plant establishment is facilitated on smaller patches arranged in a pattern across the landscape. These intensively managed patches could then serve as nuclei of seed production and as future sources of propagules for the surrounding area. Such patches might be initiated from seed or via transplantation of entire plants, plugs, or sods using specialized equipment (DePuit 1988). Groups of tree and shrub species and their associated soils have been transplanted on mined lands using tree spades and front-end loaders (McGinnies and Wilson 1982). Although labor intensive and costly, transplant approaches may ensure ecotypic adaptation, introduction of soil microorganisms, introduction of species that are incapable of rapid establishment from seed, and ensure the establishment of larger plants that are more capable of coping with competition and herbivory.

Moody and Mack (1988) analyzed factors that contribute to the spread of invading plants by simulating various regimes of repeated control. Control regimes included reducing the area of the main stand or destroying some proportion of the smaller satellite stands. Results indicated that spread of species was primarily regulated by the dynamics of satellite stands rather than expansion of the initially large stand. Their simulations suggest that the rate of spread of desirable species might be enhanced by concentrating resources (e.g., seed, fertilizer, and water) to facilitate the development of satellite stands that could subsequently produce seed for natural dispersal rather than spreading those same resources uniformly across an area. Determining the size and arrangement of satellite patches on the landscape falls under the purview of landscape ecology (Neveh and Lieberman 1984, Forman and Godran 1986, Urban et al. 1987) and will not be explored in this paper. A knowledge of seed dispersal patterns and processes would be useful when planning and designing the placement of patches or satellite stands on the landscape. Wind and water are important vectors of seed dispersal for many species. In this paper, we will focus on animals as dispersal agents. Although opportunities exist to utilize wild and domestic animals as agents of seed dispersal to enhance restoration efforts, these must be weighed against negative aspects that may jeopardize the success of the restoration effort (e.g., granivory, dispersal of undesirable species, and excessive herbivory on desirable species).

The relative effectiveness of various agents of seed dispersal are difficult to evaluate, since there is no necessary correlation between numbers of seeds distributed by a particular agent and the value of that form of dispersal (Davidson and Morton 1984). The most effective agent of seed dissemination would transport large numbers of seeds and would deposit them in a germinable form in a microenvironment suitable for establishment. Thus, an animal hat simply transports large numbers of seeds is not necessarily an effective agent of dispersal. Conversely, animals that transport relatively fewer seeds are not necessarily poor vectors.

There is a fine line separating seed predation from seed dispersal in many instances. Seeds dispersed by some animals may escape predation by others. Seeds that escape mastication after ingestion by animals may be regurgitated or survive passage through the digestive tract and be deposited with feces. Ants in some cases (myremecochory), discard seeds after nutrients have been extracted from external structures (elaiosomes). Granivorous rodents may place seeds in caches where seeds may remain unutilized. Recruitment could be enhanced in each of these cases if probabilities of seed germination and seedling establishment were increased relative to those of undispersed seed.

There are numerous examples demonstrating enhanced germination among seeds manipulated by animals relative to seeds not manipulated (Howe and Smallwood 1982). Enhanced establishment could also be achieved if dispersed seeds were consistently deposited in "safe sites" (Harper 1977). Safe sites for establishment may occur away from conspecific adults which harbor seed or seedling predators or may occur in selected habitats and microsites where resource availability is greater. For example, caching by rodents may result in seeds being buried at depths conducive to germination (Howe 1977), in the placement of seeds in microsites where seedling survival may be enhanced as a result of better light or soil properties, and in escape from seed and seedling predators associated with parent plants (Janzen 1970, Lignon 1978, Webb and Wilson 1985, Howe et al. 1985). Seed-caching or scatterhoarding by rodents has been implicated as important for indian ricegrass (Oryzopsis hymenoides (R. \& S.) Ricker; McAdoo et al. 1983), bitterbrush (Purshia tridentata (Pursh) DC.; West 1968), creosotebush (Larrea tridentata (DC) Cov.; Chew and Chew 1970, Sheps 1973), Opuntia spp. and mesquite (Prosopis juliflora (Sw.) DC.) (Reynolds and Glendening 1949, Reynolds 1950), and oak (Quercus spp.) and beech (Fagus spp.) (Jensen 1985, Miyaki and Kikuzawa 1988). Smith and Reichman (1984) present an in-depth review of seed caching by birds and mammals.

Other factors held equal, recruitment on a site could be increased by increasing the immigration of seeds. This could be achieved in several ways. One approach would be to design the size, arrangement and density of seed-producing "islands" on a site so as to reduce distances seeds must travel. Where animals are important agents of dispersal, provisions for suitable cover and food should be made in reclamation plans. For example, the seed rain of bird-dispersed plants into abandoned fields was increased an order of magnitude when natural and artificial perching structures were provided (McDonnell and Stiles 1983).

Given the large numbers and high concentrations of livestock on many rangelands, their role in seed dispersal warrants specific consideration. Seed dispersal by adhesion (epizoochory) is an evolved adaptation of many low-statured plants of woodlands and disturbed areas (Sorenson 1986), and livestock have contributed to the introduction and spread of exotic weeds via this dispersal method (Benson and Walkington 1965, Mack 1981). Observations of large numbers of seedlings of Prosopis and Acacia spp. emerging from dung of ungulates have been made on 4 continents (Paulsen 1950, Lamprey et al. 1974, Gutierrez and Armesto 1981, Harvey 1981) and the rapid spread of these hard-seeded legumes is testimony to the effectiveness of livestock as dispersal agents (Brown and Archer 1987). Livestock grazing in autumn or winter breaks inflorescences of crested wheatgrass (Agropyron desertorum (Fisch. ex Link) Shultz.), thereby increasing the potential for germination of seeds retained on the spike by placing them in contact with soil (Pyke 1990). In this example, season of grazing is an important consideration. 
Ungulates may also ingest and disperse seeds of a variety of herbaceous species while consuming foliage (Janzen 1984); however, there have been few attempts to use this knowledge of livestock as agents of seed dispersal to aid the establishment and spread of desirable species. Livestock could be strategically fed seeds of desirable species or allowed to graze in areas where the density of desirable, seed-producing plants is high. Once dosed, animals could be released to disseminate seeds into areas targeted for improvement.

This approach, if successful, could potentially offer several biological and economic advantages over conventional reseeding approaches. The most extensive and least expensive methods of seed application (e.g., broadcast seeding) typically meet with the lowest success. Practices ensuring good seed-soil contact are expensive and difficult to apply extensively, especially where brush, rocks, and rough topography predominate. In contrast, a potentially significant proportion of seeds ingested by cattle would be deposited in a moist, nutrient-rich medium that may facilitate germination and establishment. Depending on rate of seed passage and on patterns of animal movement, viable seeds could be distributed over large areas for several days after dosing. The cost of this approach would be relatively low. Emergence of seedlings in dung may occur over long periods, especially where hard-seeded species are involved. The result could be the development of a high density of patches of desirable species that could subsequently serve as local seed sources in the community. For this scheme to work, grazing management would have to be closely regulated, especially at the critical seedling establishment stage, so that livestock did not over-utilize and eliminate the very plants they were spreading.

Major questions relative to actively utilizing livestock as agents of seed dispersal of desirable species pertain to seed survival, to the rate of passage through the digestive tract (a function of seed size, hardness and specific gravity, and of animal diet), to rates of germination in dung, and to subsequent seedling establishment (Fig. 1). Soft-seeded species may lose viability and germinability

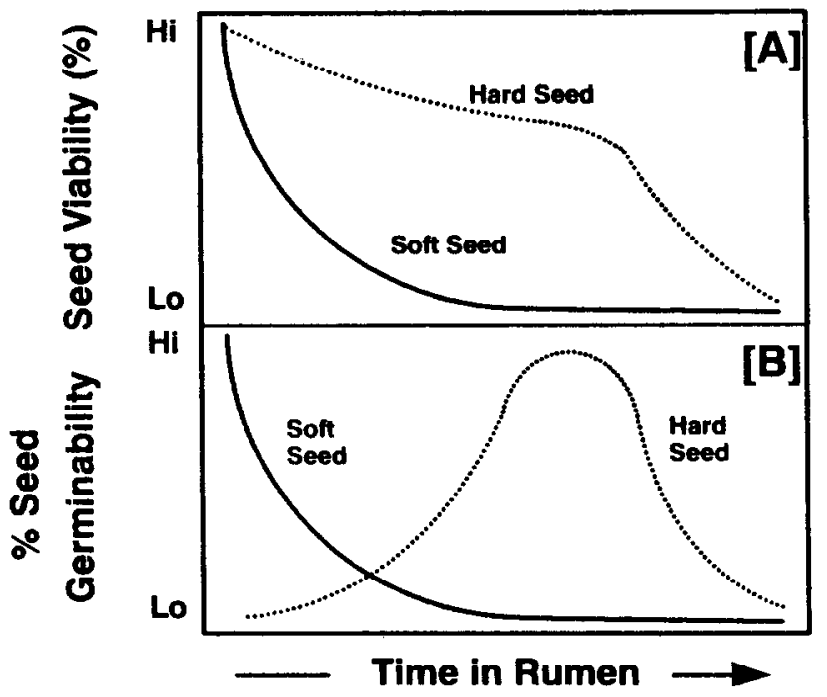

Fig. 1. Hypothetical functions for ingested seeds relating changes in seed viability and germinability to time in rumen.

quickly. Species with hard seed coats may lose viability more slowly. However, seeds passing through the rumen quickly may not be scarified and hence have low germinability. Once scarified in the rumen, additional time in the rumen may be detrimental to seed viability and germinability (Fig. 1). These issues have been addressed to varying degrees for some plant and livestock species (Burton and Andrews 1948, Yamada and Kawaguchi 1972, Welch
1985, Simao Neto et al. 1987, Jones and Simao Neto 1987). Results to date suggest sufficient potential to warrant continued investigation.

\section{Herbivory}

Herbivory is the main plant-animal interaction which has been investigated in rangeland ecosystems. Activities of root-feeding nematodes, leaf-chewing grasshoppers, termites, herbivorous rodents, lagomorphs, and large mammals interact with livestock to affect rangeland vegetation. Seasonal and annual fluctuations in the abundance of arthropod and wildlife populations are difficult to obtain. As a result, estimates of numbers of these organisms and of their impact on plants relative to that of livestock is difficult to determine.

The debate over the effects of grazing (positive, neutral, negative) with regard to aboveground net primary production (Belsky 1986,1987, McNaughton 1986) is often confounded by comparing across levels of organization (e.g., individual plants versus plant communities) and across gradients of resource availability. In addition, the debate may be largely academic for arid and semiarid regions where livestock grazing intensity is usually far in excess of that which might optimize aboveground net primary production (Piper and Heitschmidt 1988). Community-level response to grazing will vary, depending upon the evolutionary history of the species and the systems in which they occur (Milchunas et al. 1988). Plant response to herbivory will depend on an array of interacting factors including the frequency, magnitude, and season of tissue removal; the type of plant part(s) lost; levels of resource availability and competition; and stage of life cycle (Archer and Smeins 1991, Briske 1991). Species-rich plant communities are potentially more resilient than species-poor communities following grazing (Brown and Ewel 1988).

Most research has emphasized the effects of aboveground grazers on vegetation, but belowground herbivores may consume more plant material (Coleman et al. 1976, Stanton 1988). Nematodes, grass grubs (beetle larvae in Scarabaeidae), and scarab larvae (Phyllophaga crinita (Burm.)) that consume roots cause significant plant mortality and reductions in shoot production (Ueckert 1979, Detling et al. 1980, Stanton et al. 1981). Estimates of decreased plant production resulting from nematode herbivory range from 6-13\% in grassland ecosystems (Ingham and Detling 1984) to $1-10 \%$ in agricultural systems (Sohlenius et al. 1988). Aboveground grazing on grasses appears to increase their susceptibility to parasitic nematodes belowground (Stanton 1983, Ingham and Detling 1984). Methods for preparing a site for revegetation that kill the existing vegetation may reduce numbers of belowground herbivores by reducing their food supply. However, if seeds are sown and germinate before reductions in these invertebrate populations occur, or are sown into land with existing vegetation, then these unseen organisms could potentially limit the establishment of seedlings. This is an area of limited research and warrants further study.

Plant adaptations to herbivory fall into 2 major categories: grazing tolerance and grazing avoidance (Table 1). Grazing tolerant plants have characteristics that facilitate the reestablishment of foliage following grazing, whereas plants that avoid grazing have morphological or physiological characteristics (e.g., thorns, secondary chemical compounds) that minimize the probability of defoliation (Archer and Tieszen 1980, Mooney and Gulmon 1982, Briske 1986). Plants with traits conferring grazing avoidance are typically stress tolerators, whereas plants tolerant of defoliation often have characteristics of competitive plants (Pyke and Archer 1991). Trade-offs between competitive ability and tolerance to defoliation may also exist. Windle and Franz (1979) found that cultivars susceptible to insect attack were the superior competitors 
Table 1. Characteristics of plants that resist grazing either by tolerating or avoiding defoliation (adapted from Briske 1986).
Grazing tolerance

Grazing tolerance
Migh number of active meristems
present after grazing.

Grazing avoidance

Axillary buds near soil surface or on less preferred branches.

Horizontal leaf and branch angles.

High stem and sheath to leaf blade ratio.

Prostrate growth form.

Mechanical defenses - e.g., awns, pubescence, spines and thorns.

Small foliage elements.

Physiological

High relative growth rate. High nutrient reserves. High carbohydrate reserves?

High content of lignin, silica or epicuticular waxes.

High levels of secondary compounds. and physiological adaptations for tolerance to herbivory must therefore be evaluated in the context of relative grazing intensity among species in a stand. Plants which are highly tolerant of defoliation will be disadvantaged when competing with associated species which, although less tolerant of grazing, may be defoliated less frequently or intensely (Mueggler 1972, Archer and Detling 1984, Caldwell 1984). For this reason, species chosen for revegetation of rangelands that will be grazed should be dominated by plants with adaptations conferring grazing tolerance. Mixing grazing-tolerant and grazing-avoidance species will inevitably lead to dominance by species which avoid grazing.

Grazing during early stages of seedling establishment may be considered predation based on the strict definition by Thompson (1982) if it causes death of the plant. Seedlings are particularly sensitive to herbivory in that they have low levels of nutrient or energy reserves and shallow, low-density root systems relative to adult plants. Stage of root development is important for anchoring grazed plants. Meadow voles (Microtus montanus Peale) are capable of uprooting grass seedlings during the grazing process (Pyke 1987). Species differ in how soon after germination they can be grazed without being uprooted. The desire to have livestock graze plants as early as possible after revegetation has led to the development of grasses such as 'Hycrest'crested wheatgrass (Agropyron cristatum (L.) Gaertn. $X$ desertorum). The lateral root production of 'Hycrest' is similar to that of cheatgrass (Bromus tectorum L.) (Aguirre and Johnson 1991) indicating that these species may be similar in their ability to resist uprooting while young.

Differences in seed size within and between species affects the rate and timing of germination and the subsequent growth rate and competitive ability of seedlings. There is generally a direct relationship between seed size and seedling performance (Harper 1977). As a result, use of large-seeded taxa with their greater seedling growth rates, may improve chances of establishment in the face of herbivory, competition, and various abiotic stresses. Defoliation can influence subsequent seedling recruitment and stand dynamics by reducing the number and size of seeds that plants produce (Crawley 1983, Jameson 1963, Maun and Cavers 1971a,b).

Because plants are relatively sensitive to defoliation early in their life cycle, deferment of grazing is often helpful, if not necessary, to ensure plant establishment. Deferment during early stages of restoration represents a "cost" in terms of missed opportunity (e.g., loss of revenue) and in terms of expenditures associated with supplementation or boarding of animals elsewhere. However, if grazing too soon after seeding significantly jeopardizes plant establishment, then the restoration effort is doomed to economic failure from the outset. Similarly, the long-term success of a restoration project will hinge on post-establishment grazing management. Plant recovery from grazing can be enhanced while persistence, productivity, and botanical composition can be sustained, but only if proper stocking rates are maintained. This requires matching grazing and rest intervals with the phenology and life history attributes of key plant species (Holechek 1983, Valentine 1989, Heitschmidt and Stuth 1991).

\section{Conclusions}

Land managers in the past selected species for revegetation by relying heavily on phytosociological correlations between latesuccessional species and their environment. Although phytosociology is important in species selection, the land manager of the future should be more like a repair person than a sociologist (Harper 1987). If a piece of equipment is broken, the repair person need not categorize or correlate the equipment (vegetation community) with the place it is used (environment) to fix it. They require a kit of appropriate tools and components and they require a knowledge of the mechanisms that interact in the equipment to 
make it work. Land managers require certain tools and components (e.g., plant materials, nutrients, equipment) to use in conjunction with a knowledge of ecosystem processes for successful rangeland revegetation or restoration.

An understanding of plant autecology and plant-environment relationships is crucial to the success of restoration efforts. Biotic interactions, both plant-plant and plant-animal, will operate against a backdrop of edaphic and climatic constraints to further regulate and determine patterns of species distribution, abundance, and persistence over time. Much of our knowledge of the outcome of biotic interactions has come from and will continue to come from attempts to solve applied problems (Harper 1987, Slobodkin 1988) such as those associated with the reconstruction of vegetation communities on disturbed lands. In addition, revegetation and restoration projects offer unique opportunities to investigate species interactions at spatial and temporal scales not generally available in most research environments. Properly designed baseline studies aimed at ascertaining the mechanisms involved in biotic interactions would make a significant contribution to our working knowledge of ecological principles pertinent to rangeland revegetation and restoration.

\section{Literature Cited}

Abramsky, Z. 1983. Experiments on seed predation by rodents and ants in the Israeli desert. Oecologia 57:328-332.

Aguirre, L., and D.A. Johnson. 1991. Root morphological development in relation to shoot growth in seedlings of four range grasses. J. Range Manage. 44:341-346.

Alexander, M. 1977. Introduction to soil microbiology, 2nd Ed. Wiley \& Sons, N.Y.

Allen, E.B. 1988. Some trajectories of succession in Wyoming sagebrush grassland: Implications for restoration, p. 89-112. In: E.B. Allen (ed), The reconstruction of distrubed arid lands. Amer. Assoc. Adv. Sci., Symp. Ser. 109. Westview Press, Boulder, Colo.

Allen, E.B. 1989. The restoration of disturbed arid landscapes with special reference to mycorrhizal fungi. J. Arid Environ. 17:279-286.

Allen, M.F. 1989. Mycorrhizae and rehabilitation of disturbed arid soils: process and practices. Arid Soil Res. 3:229-241.

Archer, S., and J.K. Detling. 1984. The effects of defoliation and competition on regrowth of tillers of two North American mixed-grass prairie graminoids. Oikos 43:351-357.

Archer, S., and F.E. Smeins. 1991. Ecosystem-level processes. p. 109-139. In: R.K. Heitschmidt and J.W. Stuth (eds), Grazing management: An ecological perspective. Timber Press, Portland, Ore.

Archer, S., and L.L. Tieszen. 1980. Growth and physiological responses of tundra plants to defoliation. Arct. Alp. Res. 12:531-552.

Archer, S., and L.L. Tieszen. 1983. Effects of simulated grazing on foliage and root production and biomass allocation in an arctic tundra sedge (Eriophorum vaginatum). Oecologia 58:92-102.

Archer, S., and L.L. Tieszen. 1986. Plant response to grazing: Hierarchical considerations, p. 45-59. In: O. Gudmundsson (ed), Grazing research at northern latitudes. Plenum Publ. Co., N.Y.

Augspurger, C.K. 1980. Mass-flowering of a tropical shrub (Hybanthus prunifolius): Influence on pollinator attraction and movement. Evolution 34:475-488.

Augspurger, C.K. 1981. Reproductive synchrony of a tropical shrub: Experimental studies on effects of pollinators and seed predators on Hybanthus prunifolius (Violaceae). Ecology 62:775-788.

Bartholomew, B. 1970. Bare zone between California shrub and grassland communities: The role of animals. Science 170:1210-1212.

Batzli, G.O., and F.A. Pitelka. 1970. Influence of meadow mouse populations on California grassland. Ecology 51:1027-1039.

Belsky, A.J. 1986. Does herbivory benefit plants? A review of the evidence. Amer. Natur. 127:870-892.

Belsky, A.J. 1987. The effects of grazing: Confounding of ecosystem, community, and organism scales. Amer. Natur. 129:777-783.

Benson, L., and D.L. Walkington. 1965. The southern California pricklypears: Invasion, adulteration, and trial by fire. Ann. Miss. Bot. Gard. 52:262-273.

Bierzychudek, P. 1981. Pollinator limitation of plant reproductive effort. Amer. Natur. 117:838-840. ierzychudek, P. 1982. The demography of Jack-in-the-pulpit, a forest perennial that changes sex. Ecol. Monogr. 52:335-351.

Borchert, M.I., and S.K. Jain. 1978. The effect of rodent seed predation on four species of California annual grasses. Oecologia 33:101-113.

Briske, D.D. 1986. Plant response to defoliation: Morphological considerations and allocation priorities, p. 425-427. In: P.J. Joss, P.W. Lynch, and O.B. Williams (eds), Rangelands: A resource under siege. Proc. Second Internat. Rangel. Congr. Australian Acad. Sci., Canberra.

Briske, D.D. 1991. Developmental morphology and physiology of grasses p. 85-108. In: R.K. Heitschmidt and J.W. Stuth (eds), Grazing management: An ecological perspective. Timber Press, Portland, Ore.

Brown, B.J., and J.J. Ewel. 1988. Response to defoliation of species-rich and monospecific tropical plant communities. Oecologia 75:12-19.

Brown, J.R., and S. Archer. 1987. Woody plant seed dispersal and gap formation in a North American subtropical savanna woodland: The role of domestic herbivores. Vegetatio 73:73-80.

Buckley, R.C. (ed). 1982. Ant-plant interactions in Australia. Dr. Junk Publ., The Hague.

Burton, G.W., and J.S. Andrews. 1948. Recovery and viability of seeds of certain southern grasses and lespedeza passed through bovine digestive tract. J. Agr. Res. 76:95-103.

Caldwell, M.M. 1984. Plant requirements for prudent grazing, p. $117 \quad 152$. In: Developing strategies for rangeland management. Nat. Acad. Sci., Westview Press, Boulder, Colo.

Caldwell, M.M., J.H. Richards, J.H. Manwaring, and D.M. Eissenstat. 1987. Rapid shifts in phosphate acquisition show direct competition between neighboring plants. Nature 327:615-616.

Chew, R.M., and A.E. Chew. 1970. Energy relationships of the mammals of a desert shrub (Larrea tridentata) community. Ecol. Monogr. 40:1-21.

Coleman, D.C., R. Andrews, J.E. Ellis, and J.S. Singh. 1976. Energy flow and partitioning in selected man-managed and natural ecosystems. Agro-Ecosystems 3:45-54.

Corman, A., Y. Crozat, and JC. Cleyet-Marel. 1987. Modeling survival kinetics of some Bradyrhizobium japonicum strains in soils. Biol. Fert. Soils 4:79-84.

Crawley, M.J. 1983. Herbivory. Univ. Calif. Press, Berkeley.

Davidson, D.W., and S.R. Morton. 1984. Dispersal adaptations of some Acacia species in the Australian zone. Ecology 65:1038-1051.

DePuit, E.J. 1988. Productivity of reclaimed lands-rangelands, p. 94-129. In: L.R. Hossner (ed), Reclamation of surface-mined lands, Vol. II. CRC Press, Boca Raton, Fla.

Detling, J.K., D.J. Winn, C. Proctor-Gregg, and E.L. Painter. 1980. Effects of simulated grazing by belowground herbivores on growth, $\mathrm{CO}_{2}$ exchange and carbon allocation patterns of Bouteloua gracilis. J. Appl. Ecol. 17:771-778.

Fankhauser, J.J., and J.J. Volenec. 1989. Root vs. shoot effects on herbage regrowth and carbohydrate metabolism of alfalfa. Crop Sci. 29:735-740.

Forman, R.T.T., and M. Godron. 1986. Landscape ecology. John Wiley \& Sons, N.Y

Frankland, J.C., and A.F. Harrison. 1985. Mycorrhizal infection of Betula pendula and Acer pseudoplatanus: Relationships with seedling growth and soil factors. New Phyt. 101:133-151.

Gutierrez, J.R., and J.J. Armesto. 1981. El rol del ganado en la dispersion de las semillas de Acacia caven (Leguminosae). Ciencia Invest. Agrar. 8:3-8.

Harper, J.L. 1977. Population biology of plants. Academic Press, San Francisco, Calif.

Harper, J.L. 1987. The heuristic value of ecological restoration, p. 31-45. In: W.R. Jordan III, M.E. Gilpin, and J.D. Aber (eds), Restoration ecology: A synthetic approach to ecological research. Cambridge Univ. Press, N.Y.

Harvey, G.J. 1981. Recovery and viability of prickly acacia (Acacia nilotica ssp. indica) seed ingested by sheep and cattle, p. 197-201. In: Proc. Sixth Australian Weeds Conf., Vol. 1.

Heitschmidt, R.K., and J.W. Stuth. (eds). 1991. Grazing management: an ecological perspective. Timber Press, Portland, Ore.

Holechek, J.L. 1983. Considerations concerning grazing systems. Rangelands. 5:208-211.

Holechek, J.L., R.D. Pieper, and C.H. Herbel. 1989. Range management. Prentice Hall, Englewood Cliffs, N.J.

Holland, A.A. 1966. Studies on microbial antagonism in the establishment of clover pasture. I. The number of species and percentage frequency of occurrence of the major fungi. Plant and Soil 25:238-248. 
Holland, A.A., and C.A. Parker. 1966. Studies on microbial antagonism in the establishment of clover pasture. II. The effect of saprophytic soil fungi upon Rhizobium trifollii and the growth of subterranean clover. Plant and Soil 25:329-340.

Howe, H.F. 1977. Bird activity and seed dispersal of a tropical wet forest tree. Ecology 58:539-550.

Howe, H.F., E.W. Schupp, and L.C. Westley. 1985. Early consequences of seed dispersal for a neotropical tree (Virola sunrinamensis). Ecology 66:781-791.

Howe, H.F., and J. Smallwood. 1982. Ecology of seed dispersal. Annu. Rev. Ecol. Syst. 13:201-228.

Ingham, R.E., and J.K. Detling. 1984. Plant-herbivore interactions in a North American mixed-grass prairie. III. Soil nematode populations and root biomass on Cynomys ludovicianus colonies and adjacent uncolonized areas. Oecologia 63:307-313.

Jameson, D.A. 1963. Responses of individual plants to harvesting. Bot. Rev. 29:532-94.

Janos, D.P. 1988. Mycorrhiza applications in tropical forestry: Are temperate-zone approaches appropriate? p. 133-188. In: S.P. $\mathrm{Ng}$ (ed), Trees and mycorrhiza. Forest Research Institute, Kuala Lumpur, Malaysia.

Janzen, D.H. 1970. Herbivores and the number of tree species in tropical forests. Amer. Natur. 104:501-528.

Janzen, D.H. 1971. Seed predation by animals. Annu. Rev. Ecol. Syst. 2:465-492.

Janzen, D.H. 1976. Why bamboos wait so long to flower. Annu. Rev. Ecol. Syst. 7:347-391.

Janzen, D.H. 1984. Dispersal of small seeds by big herbivores: Foliage is the fruit. Amer. Natur. 123:338-353.

Jenkens, M.B., R.A. Virginia, and W.M. Jarrell. 1988. Depth distribution and seasonal population fluctuations of mesquite-nodulating rhizobia in warm desert ecosystems. Soil Sci. Soc. Amer. J. 52:1644-1660.

Jensen, T.S. 1985. Seed-seed predator interactions of European beech, Fagus silvatica and forest rodents, Clethrionomys glareolus and Apodemus flavicollis. Oikos 44:149-156.

Johnson, H.B., and H.S. Mayeux, Jr. 1990. Prosopis glandulosa and the nitrogen balance of rangelands: Extent and occurrence of nodulation. Oecologia 84:176-185.

Jones, R.M., and M. Simao Neto. 1987. Recovery of pasture seed ingested by ruminants. 3 . The effects of the amount of seed in the diet and of diet quality on seed recovery from sheep. Australian J. Exp. Agr. 27:253-256.

Kleiner, E.F., and K.T. Harper. 1977. Soil properties in relation to cryptogamic ground cover in Canyonlands National Park. J. Range Manage. 30:202-205.

Lamprey, N.F., G. Halevy, and S. Makacha. 1974. Interactions between Acacia, burchid seed beetles, and large herbivores. E. Afr. Wildl. J. 12:81-85.

Lignon, J.D. 1978. Reproductive interdependence of pinon jays and pinon pines. Ecol. Monogr. 48:111-126.

Loope, W.L., and G.F. Gifford. 1972. Influence of a soil microfloral crust on select properties of soils under pinyon-juniper in southeastern Utah. J. Soil Water Conserv. 27:164-167.

Louda, S.M. 1982. Distribution ecology: Variation in plant recruitment over a gradient in relation to insect seed predation. Ecol. Monogr. 52:25-41.

Lowther, W.L., D.A. Johnson, and M.D. Rumbaugh. 1987a. Distribution and symbiotic effectiveness of Rhizobium meliloti in rangeland soils of the Intermountain West. J. Range Manage. 40:264-267.

Lowther, W.L., M.D. Rumbaugh, and D.A. Johnson. 1987b. Populations of Rhizobium meliloti in areas with rangeland alfalfa. J. Range Manage. 40:268-271.

Lynch, J.M., and E. Brage. 1985. Microorganisms and soil aggregate stability. Adv. Soil Sci. 2:133-171.

Mack, R.N. 1981. Invasion of Bromus tectorum L. into western North America: An ecological chronicle. Agro-Ecosystems 7:145-165.

MacMshon, J.A. 1987. Disturbed lands and ecological theory: An essay about a mutualistic association, p. 221-237. In: W.R. Jordan III, M.E. Gilpin, and J.D. Aber (eds), Restoration ecology: A synthetic approach to ecological research. Cambridge Univ. Press, N.Y.

Mares, M.A., and M.L. Rosenzweig. 1978. Granivory in North and South American deserts: Rodents, birds and ants. Ecology 59:235-241.

Martell, A.M. 1983. Demography of southern red-backed voles (Clethrionomys gapperi) and deer mice (Peromyscus maniculatus) after logging in north-central Ontario. Can. J. Zool. 61:958-969.

Maun, M.A., and P.B. Cavers. 1971a. Seed production in Rumex crispus. I. The effects of removal of cauline leaves at anthesis. Can. J. Bot. 49:1123-1130.
Maun, M.A., and P.B. Cavers. 1971b. Seed production in Rumex crispus. II. The effects of removal of various proportions of flowers at anthesis. Can. J. Bot. 49:1841-1848

McAdoo, K., C.C. Evans, B.A. Roundy, J.A. Young, and R.A. Evans. 1983. Influence of heteromyid rodents on Oryzopsis hymenoides germination. J. Range Manage. 36:61-64.

McDonnell, M.J., and E.W, Stiles. 1983. The structural complexity of old field vegetation and the recruitment of bird-dispersed plant species. Oecologia 56:109-116.

McGinnies, W.J., and A.M. Wilson. 1982. Using blue grama sod for range revegetation. J. Range Manage. 35:259-261.

McNaughton, S.J. 1986. On plants and herbivores. Amer. Natur. 128:767770.

Milchunas, D.G., O.E. Sala, and W.K. Lauenroth. 1988. A generalized model of the effects of grazing by large herbivores on grassland community structure. Amer. Natur. 132:87-106.

Miller, R.M. 1987. Mycorrhizae and succession, p. 205-219. In: W.R. Jordan III, M.E. Gilpin, and J.D. Aber (eds), Restoration ecology: A synthetic approach to ecological research. Cambridge Univ. Press, N.Y.

Mittlebach, G.G., and K.L. Gross. 1984. Experimental studies of seed predation in old-fields. Oecologia 65:7-13.

Miyaki, M., and K. Kikuzawa. 1988. Dispersal of Quercus mongolica acorns in a broadleaved deciduous forests. 2 . Scatterhoarding by mice. Forest Ecol. Manage. 25:9-16.

Moody, M.E., and R.N. Mack. 1988. Controlling the spread of plant invasions: The importance of nascent foci. J. Appl. Ecol. 25:1009-1021.

Mooney, H.A., and S.L. Gulmon. 1982. Constraints on leaf structure and function in reference to herbivory. BioSci. 32:198-206.

Mormann, T., and F.B. Reeves. 1979. The role of endomycorrhizae in revegetation practices in the semiarid west. II. A bioassay to determine the effects of land disturbance on endomycorrhizal populations. Amer. J. Bot. 66:14-18.

Mueggler, W.F. 1972. Influence of competition on the response of Idaho fescue to clipping. J. Range Manage. 25:88-92.

Nelson, J.F., and R.M. Chew. 1977. Factors affecting seed reserves in the soil of a Mojave desert ecosystem, Rock Valley, Nye County, Nevada. Amer. Midl. Natur. 97:300-320.

Nelson, J.R., A.M. Wilson, and C.J. Goebel. 1970. Factors influencing broadcast seeding in bunchgrass range. J. Range Manage. 23:163-170.

Neveh, Z., and A.S. Lieberman. 1984. Landscape ecology: Theory and application. Springer-Verlag, New York.

Parker, C.A., and D.L. Chatel. 1982. Factors determining success or failure in legume establishment, p. 145-153. In: J.M. Vincent (ed), Nitrogen fixation in legumes. Academic Press, N.Y.

Paulsen, H.A. 1950. Mortality of velvet mesquite seedlings. J. Range Manage. 3:281-286.

Perry, D.A., R. Molina, and M.P. Amaranthus. 1987. Mycorrhizae, mycorrhizospheres and reforestation: Current knowledge and research needs. Can. J. Forest Res. 17:929-940.

Perry, D.A., M.P. Amaranthus, J.G. Borchers, S.L. Borchers, and R.E. Brainerd. 1989. Bootstrapping in ecosystems. BioSci. 39:230-237.

Piper, R.D., and R.K. Heitschmidt. 1988. Is short-duration grazing the answer? J. Soil Water Conserv. 43:133-137.

Porter, W.M., A.D. Robson, and L.K. Abbott. 1987a. Field survey of the distribution of vesicular-arbuscular mycorrhizal fungi in relation to soil pH. J. Appl. Ecol. 24:659-662.

Porter, W.M., A.D. Robson, and L.K. Abbott. 1987b. Factors controlling the distribution of vesicular-arbuscular mycorrhizal fungi in relation to soil pH. J. Appl. Ecol. 24:663-672.

Powell, C.L. 1980. Mycorrhizal infectivity of eroded soils. Soil Biol. Biochem. 12:247-250.

Pyke, D.A. 1987. Demographic responses of Bromus tectorum and seedlings of Agropyron spicatum to grazing by small mammals: The influence of grazing frequency and plant age. J. Ecol. 75:825-835.

Pyke, D.A. 1990. Comparative demography of co-occurring introduced and native tussock grasses: Persistence and potential expansion. Oecologia 82:537-543.

Pyke, D.A., and S. Archer. 1991. Plant-plant interactions affecting plant establishment and persistence on revegetated rangeland. J. Range Manage. 44:550-557.

Reichman, O.J. 1979. Desert granivore foraging and its impact on seed densities and distributions. Ecology 60:1085-1092.

Reynolds, H.G. 1950. Relation of Merriam kangaroo rats to range vegetation in southern Arizona. Ecology 31:456-463. 
Reynolds, H.G. 1958. The ecology of the Merriam kangaroo rat (Dipodomys merriami Mearns) on the grazing lands of southern Arizona. Ecol. Monogr. 28:111-127.

Reynolds, H.G., and G.E. Glendening. 1949. Merriam kangaroo rat, a factor in mesquite propagation on southern Arizona rangelands. J. Range Manage. 2:193-197.

Rice, W.A., D.C. Penney, and M. Nyborg. 1977. Effects of soil acidity on rhizobia numbers, nodulation and nitrogen fixation by alfalfa and red clover. Can. J. Soil Sci. 57:197-203.

Richards, J.H. 1984. Root growth response to defoliation in two Agropyron bunchgrasses: field observations with an improved root periscope. Oecologia 64:21-25.

Richards, J.H., and M.M. Caldwell. 1985. Soluble carbohydrates, concurrent photosynthesis and efficiency in regrowth following defoliation: $A$ field study with Agropyron species. J. Appl. Ecol. 22:907-920.

Rychert, R.C., and J. Skujins. 1974. Nitrogen fixation by blue-green algaelichen crusts in the Great Basin Desert. Soil Sci. Soc. Amer. J. 38:768-771.

Sheps, L.U. 1973. Survival of Larrea tridentata S \& M. seedlings in Death Valley National Monument, California. Isr. J. Bot. 22:8-17.

Silander, J.A., and R.B. Primack. 1978. Pollination intensity and seed set in the evening primrose (Oenothera fruticosa). Amer. Midl. Natur. 100:213-216.

Silvertown, J.W. 1980. The evolutionary ecology of mast seeding in trees. Biol. J. Linn. Soc., Lond. 14:235-250.

Simao Neto, M., R.M. Jones, and D. Rateliff. 1987. Recovery of pasture seed ingested by ruminants. 1. Seed of six tropical pasture species fed to cattle, sheep and goats. Australian J. Exp. Agr. 27:239-246.

Simpson, B.B., J.L. Neff, and A.R. Moldenke. 1977. Reproductive systems of Larrea, p. 92-114. In: T.J. Mabry, J.H. Hunziker, and D.R. Difeo (eds), Creosote bush: Biology and chemistry of Larrea in New World deserts. Dowden, Hutchinson and Ross, Stroudsburg, $\mathrm{Pa}$.

Slobodkin, L.B. 1988. Intellectual problems of applied ecology. BioSci. 38:337-342.

Smith, C.C., and O.J. Reichman. 1984. The evolution of food caching by birds and mammals. Annu. Rev. Ecol. Syst. 15:329-351.

Smith, T.J., III, H.T. Chan, C.C. McIvor, and M.B. Robblee. 1989. Comparisons of seed predation in tropical, tidal forests for three continents. Ecology 70:146-151.

Sohlenius, B., S. Bostrom, and A. Sandor. 1988. Carbon and nitrogen budgets of nematodes in arable soil. Biol. Fertil. Soils 6:1-8.

Sorensen, A.E. 1986. Seed dispersal by adhesion. Annu. Rev. Ecol. Syst. 17:443-463.

Stanton, N.L. 1983. The effect of clipping and phytophagous nematodes on net primary production of blue grama, Bouteloua gracilis. Oikos 40:249-257.

Stanton, N.L. 1988. The underground in grasslands. Annu. Rev. Ecol. Syst. 19:573-589.

Stanton, N.L., M. Allen, and M. Campion. 1981. The effect of the pesticide carbofuran on soil organisms and root and shoot production in shortgrass prairie. J. Appl. Ecol. 18:417-431.

St. Clair, L.L., B.L. Webb, J.R. Johansen, and G.T. Nebeker. 1984. Cryptogamic soil crusts: Enhancement of seedling establishment in disturbed and undisturbed areas. Reclam. Reveg. Res. 3:129-136.
Stephenson, A.G. 1981. Flower and fruit abortion: Proximate causes and ultimate functions. Annu. Rev. Ecol. Syst. 12:253-280.

St. John, T.V., and D.C. Coleman. 1983. The role of mycorrhizae in plant ecology. Can. J. Bot. 61:1005-1014.

Stcddart, L.A., A.D. Smith, and T.W. Box. 1975. Range management, 3rd ed. McGraw-Hill, N.Y.

Sullivan, T.P. 1979. The use of alternative foods to reduce conifer seed predation by the deer mouse (Peromyscus maniculatus). J. Appl. Ecol. 16:475-495.

Thompson, J.N. 1982. Interaction and coevolution. John Wiley \& Sons, N.Y.

Trinick, M.J. 1982. Host-Rhizobium associations, p. 111-122. In: J.M. Vincent (ed), Nitrogen fixation in legumes. Academic Press, N. Y.

Troughton, A. 1973. Mineral nutrition and the reaction of Lolium perenne to defoliation. Plant and Soil 38:95-111.

Ueckert, D.N. 1979. Impact of white grubs (Phyllophaga crinita) on a shortgrass community and evaluation of selected rehabilitation practices. J. Range Manage. 32:445-448.

Urban, D.L., R.V. O'Neill, and H.H. Shugart. 1987. Landscape ecology. BioSci. 37:119-126.

Vallentine, J.R. 1989. Range development and improvements, 3rd ed. Academic Press, New York.

van der Pijl, L. 1972. Principles of dispersal in higher plants. SpringerVerlag, Berlin, Germany.

Vander Wall, S.B., and J.A. MacMahon. 1984. Avian distribution patterns along a Sonoran Desert bajada. J. Arid Environ. 7:59-74.

Virginia, R.W., M.B. Jenkens, and W.M. Jarrell. 1986. Depth of root symbiont occurrence in soil. Biol. Fertil. Soils 2:127-130.

Waser, N.M. 1978. Competition for hummingbird pollination and sequential flowering in two Colorado wildflowers. Ecology 59:934-944.

Webb, S.L., and M.F. Willson. 1985. Spatial heterogeneity in postdispersal predation on Prunus and Uvularia seeds. Oecologia 67:150-153.

Welch, D. 1985. Studies in the grazing of heather moorland in northeast Scotland. IV. Seed dispersal and plant establishment in dung. J. Appl. Ecol. 22:461-472.

West, N.E. 1968. Rodent-influenced establishment of ponderosa pine and bitterbrush seedlings in central Oregon. Ecology 49:1009-1011.

Willson, M.F., B.L. Rice, and M. Westoby. 1990. Seed dispersal spectra: A comparison of temperate plant communities. J. Veg. Sci. 1:547-562.

Wilson, D.E., and D.H. Janzen. 1972. Predation on Scheelea palm seeds by Bruchid beetles: Seed density and distances from the parent palm. Ecology 53:954-959.

Windle, P.N., and E.H. Franz. 1979. The effects of insect parasitism on plant competition: Green bugs and barley. Ecology 60:521-529.

Yamada, T., and T. Kawaguchi. 1972. Dissemination of pasture plants by livestock. II. Recovery, viability and emergence of some pasture plant seeds passed through the digestive tract of dairy cows. J. Jap. Grassl. Sci. 18:8-15.

Zimmerman, M. 1980. Reproduction in Polemonium: competition for pollinators. Ecology 61:497-501. 